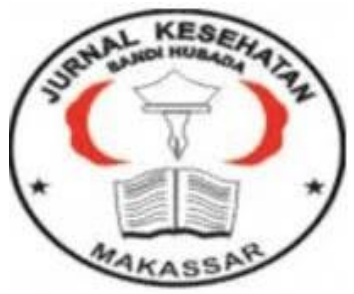

Jurnal Ilmiah Kesehatan Sandi Husada

hhttps://akper-sandikarsa.e-journal.id/JIKSH

Volume 12, Nomor 2, Desember 2020, pp 922-926

p-ISSN: 2354-6093 dan e-ISSN: 2654-4563

DOI: 10.35816/jiskh.v10i2.435

\title{
Hubungan Hipertensi Terhadap Kejadian Stroke
}

Literatur Riview

Association Between Hipertension and Stroke

Puti Nadhirah Puspitasari

Pendidikan Dokter, Fakultas Kedokteran, Universitas Lampung

Artikel info

Artikel history:

Received; Juli 2020

Revised: Agustus 2020

Accepted; September 2020
Keywords:

Stroke;

Hipertensi;

\begin{abstract}
Abstrak.
Latar belakang:Stroke didefinisikan sebagai gangguan suplai darah ke otak.Banyak faktor yang dapat memengaruhi kejadian stroke. Hipertensi merupakan faktor pencetus utama terjadinya kejadian stroke, baik stroke hemoragik ataupun iskemik. Tujuan: Mengetahui lebih lanjut mengenai hubungan hipertensi terhadap kejadian stroke. Metode: Metode yang digunakan adalah studi literatur yang diambil dari berbagai jurnal nasional dan internasional, metode ini berupaya meringkas kondisi pemahaman terkini mengenai suatu topik.Kesimpulan:Terdapat hubungan hipertensi terhadap kejadian stroke.

Abstract.

Background: Stroke is defined as a disruption in the blood supply to the brain. Many factors can affect the incidence of stroke. Hypertension is the main triggering factor of stroke, both hemorrhagic and ischemic strokes. Objective: To find out more about the relationship of hypertension to the incidence of stroke. Methods: The method used is a literature study taken from various national and international journals, this method always tries to meet the latest conditions on a topic. Conclusion: There is a relationship of hypertension with incidence of stroke.
\end{abstract}

Coresponden author: Email: putidhira@gmail.com

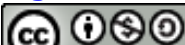

artikel dengan akses terbuka dibawah lisensi CC BY-NC-SA -4.0

\section{Pendahuluan}

Stroke didefinisikan sebagai gangguan suplai darah ke otak yang biasanya disebabkan adanya sumbatan oleh gumpalan darah. Hal ini menyebabkan gangguan pasokan oksigen dan nutrisi diotak sehingga terjadi kerusakan jaringan otak. (WHO,2016). Stroke juga dikatakan sebagai gangguan fungsi syaraf akut yang disebabkan karena gangguan peredaran darah otak secara mendadak (dalam hitungan detik) atau secara cepat (dalam hitungan jam) timbul gejala dan tanda yang sesuai dengan daerah fokal yang terganggu. Stroke terbagi dalam dua tipe, tipe pertama adalah stroke iskemik disebabkan kurangnya suplai darah ke otak dikarenakan menyempitnya atau tersumbatnya pembuluh darah oleh deposit lemak yang disebut plak sehingga jaringan otak mengalami iskemik. Tipe yang kedua adalah stroke hemoragik yang disebabkan pemecahan aneurisma pada parenchyma 
otak atau pada rongga antara otak dan tengkorak sehingga menyebabkan terjadinya iskemik dan desakan pada jaringan otak (American Heart Association, 2013).

Banyak faktor yang dapat memengaruhi kejadian stroke, diantaranya yaitu umur, jenis kelamin, keturunan, ras, hipertensi, hiperkolesterolemia, diabetes melitus, merokok, aterosklerosis, penyakit jantung, obesitas, konsumsi alkohol, stres, kondisi sosial ekonomi yang mendukung, diet yang tidak baik, aktivitas fisik yang kurang dan penggunaan obat anti hamil. Namun dari banyaknya faktor yang memengaruhi kejadian stroke hanya hipertensi yang secara signifikan memengaruhi kejadian stroke sedangkan kadar lipid dan kebiasaan merokok tidak secara signifikan berhubungan dengan kejadian stroke (Sarini,2008). Dalam 20 tahun terakhir terlihat peningkatan beban stroke terjadi secara global. WHO mengestimasi peningkatan jumlah pasien stroke di beberapa negara Eropa sebesar 1,1 juta pertahun pada tahun 2000 menjadi 1,5 juta pertahun pada tahun 2025 Prevalensi stroke di Indonesia berdasarkan wawancara sebesar 8,3\% pada tahun 2007 dan meningkat menjadi 12,1\% pada tahun 2013 (Lannywati, 2016).

Setiap tahunnya terdapat 10 juta orang di seluruh dunia menderita stroke. Diantaranya ditemukan jumlah kematian sebanyak 5 juta orang dan 5 juta orang lainnya mengalami kecacatan yang permanen dan membutuhkan bantuan untuk aktivitas kesehariannya (WHO, 2010). Di Indonesia, diperkirakan setiap tahun terjadi 500.000 penduduk terkena serangan stroke, sekitar 2,5\% dari 500.000 penderita atau 125.000 orang meninggal, dan sisanya cacat ringan maupun berat. Secara umum, dapat dikatakan angka kejadian stroke adalah 200 per 100.000 penduduk. Dalam satu tahun, di antara 100.000 penduduk, maka 200 orang akan menderita stroke (Yayasan Stroke Indonesia, 2012). Sekitar 795.000 orang di Amerika Serikat mengalami stroke setiap tahunnya, dimana sebagian besar mengalami penyakit stroke untuk yang pertama kalinya dan sebagian kecil mengalami penyakit stroke yang berulang. Lebih dari 140.000 orang meninggal setiap tahunnya akibat stroke, data tersebut menunjukkan terdapat 4 orang setiap menitnya yang meninggal karena stroke. (National Heart, Lung, and Blood Institute,2008). Stroke dikatakan sebagai penyebab kematian ketiga tersering di negara maju, setelah penyakit jantung dan kanker. Insidensi tahunan adalah 2 per 1000 populasi. Mayoritas stroke adalah infark serebral (Lionel dan Ginsberg, 2007).

Jumlah penderita penyakit stroke di Indonesia tahun 2013 berdasarkan diagnosis tenaga kesehatan diperkirakan sebanyak 1.236 .825 orang $(7,0 \%)$, sedangkan penderita yang menunjukkan gejala stroke diperkirakan sebanyak 2.137 .941 orang $(12,1 \%)$ (Pusat Data dan Informasi Kementrian Kesehatan RI,2014). Dalam tinjauan sistematis dari 36 studi epidemiologi berbasis populasi, tingkat kejadian stroke hemoragik per 100.000 orangtahun adalah 51,8\% pada orang Asia, 24,2\% di Whites, 22,9\% di Blacks, dan 19,6\% di Hispanik (Sang Joon An,2017).

\section{Metode}

Metode yang digunakan adalah studi literatur yang diambil dari berbagai jurnal nasional dan internasional, metode ini berupaya meringkas kondisi pemahaman terkini mengenai suatu topik. Studi literatur memberikan ringkasan berupa publikasi terbaik dan paling relevan kemudian membandingkan hasil yang disajikan makalah. Studi literatur menyajikan ulang materi yang pernah diterbitkan sebelumnya,membandungkan dan menyatukan hasil-hasil temuan dari literatur-literatur terdahulu dan melaporkan fakta. Tinjauan literatur menentukan berbagai persamaan dan perbedaan berbagai hasil temuan serta memberikan ringkasan berupa publikasi terbaik dan paling relevan yang disajikan dalam artikel. 


\section{Hasil Dan Pembahasan}

Stroke secara klasik dicirikan sebagai defisit neurologik dikaitkan dengan cedera fokal akut dari sistem saraf pusat (SSP) yang dikarenakan sebab vaskular, termasuk infark serebral, intracerbral hemmorhage (ICH) dan subarchnoid hemmorhage (SAH) dan merupakan penyebab utama kecacatan dan kematian di seluruh dunia (Sacco et al.,2013). Hipertensi adalah suatu keadaan dimana tekanan darah sistolik lebih dari sama dengan $140 \mathrm{mmHg}$ dan diastolik lebih dari sama dengan $90 \mathrm{mmHg}$ dalam pengukuran berulang.Faktor risiko dari hipertensi secara garis besar dibagi dua, yaitu faktor risiko yang tidak dapat dimodifikasi seperti genetik, usia, dan jenis kelamin dan faktor risiko yang dapat dimodifikasi seperti obesitas, stres, merokok, minum alkohol, konsumsi garam berlebih, dan sebagainya (Ade Y\&Arif S, 2016) Hipertensi merupakan faktor pencetus utama terjadinya kejadian stroke,baik stroke hemoragik ataupun iskemik. Hipertensi menyebabkan peningkatan tekanan darah perifer sehingga menyebabkan sistem hemodinamik yang buruk dan terjadilah penebalan pembuluh darah serta hipertrofi dari otot jantung. Hal ini dapat diperburuk dengan kebiasaan merokok dan mengonsumsi makanan tinggi lemak serta garam oleh pasien yang mana dapat menimbulkan plak aterosklerosis. Hipertensi yang menimbulkan plak aterosklerosis secara terus menerus akan memicu timbulnya stroke. Hipertensi dapat menyerang siapa saja dari berbagai kelompok usia. (Yoggie,2014). Penelitian yang dilakukan oleh Cintya, dkk (2012) mendapatkan hasil bahwa faktor risiko tertinggi pada semua pasien stroke adalah hipertensi $(82,30 \%)$, pada pasien dengan stroke ischemic kadar gula darah meningkat $(47,89 \%)$, sedangkan pada pasien stroke hemorrhagic adalah faktor risiko utama adalah hipertensi (100,00\%).

Berdasarkan penelitian yang dilakukan di Rumah Sakit Krakatau Medika periode 1 Januari-31 Desember 2011 oleh Dian Nastiti juga didapatkan hasil yang sama, stroke ischemic lebih banyak dibandingkan stroke hemorrhagic, yang mana dari 152 pasien, 85\% penderita stroke ischemic dan hanya $15 \%$ penderita stroke hemorrhagic, $46 \%$ dari seluruh pasien stroke yang diteliti, yang merupakan jumlah terbanyak mempunyai faktor risiko hipertensi yang diikuti secara berturut-turut oleh prehipertensi dan tekanan darah normal. Penelitian lain menyebutkan tekanan darah tinggi adalah faktor risiko paling umum dari stroke, karena menyebabkan tegangan yang tidak diperlukan di pembuluh darah menjadi tebal dan memburuk yang akhirnya dapat menyebabkan terjadinya stroke. Ketika pembuluh darah menebal disertai tekanan darah yang meningkat, kolesterol dan substansi lemak yang lainnya dapat menyebabkan rusaknya dinding arteri dan penyumbatan di arteri otak, peningkatan tegangan yang terjadi pada pembuluh darah otak juga dapat menyebabkan dinding pembuluh darah melemah yang akhirnya dapat menyebabkan pembuluh darah tersebut pecah dan akhirnya terjadi stroke. (Alving,2007)

Yoggie (2014) mengatakan hipertensi merupakan faktor pencetus utama terjadinya kejadian stroke, baik stroke hemoragik ataupun iskemik. Hipertensi menyebabkan peningkatan tekanan darah perifer sehingga menyebabkan sistem hemodinamik yang buruk dan terjadilah penebalan pembuluh darah serta hipertrofi dari otot jantung. Hal ini dapat diperburuk dengan kebiasaan merokok dan mengonsumsi makanan tinggi lemak serta garam oleh pasien yang mana dapat menimbulkan plak aterosklerosis, hipertensi yang menimbulkan plak aterosklerosis secara terus menerus akan memicu timbulnya stroke.

Bila tekanan darah meningkat cukup tinggi selama berbulan-bulan atau bertahun- tahun, akan menyebabkan hialinisasi pada lapisan otot pembuluh darah serebral. Akibatnya, 
diameter lumen pembuluh darah tersebut akan menjadi tetap. Hal ini berbahaya karena pembuluh serebral tidak dapat berdilatasi atau berkonstriksi dengan leluasa untuk mengatasi fluktuasi dari tekanan darah sistemik. Bila terjadi kenaikan tekanan darah sistemik maka tekanan perfusi pada dinding kapiler menjadi tinggi. Akibatnya, terjadi hiperemia, edema, dan kemungkinan perdarahan pada otak. Pada hipertensi kronis dapat terjadi mikroaneurisma dengan diameter $1 \mathrm{~mm}$ (terutama terjadi pada arteri lentikulostriata). Pada lonjakan tekanan darah sistemik, sewaktu orang marah atau mengejan, aneurisma bisa pecah. Hipertensi yang kronis merupakan salah satu penyebab terjadinya disfungsi endotelial dari pembuluh darah (Hariyono, 2006).

Hipertensi dapat menimbulkan perubahan patologik yang berbeda pada pembuluh darah sedang dan pembuluh darah kecil otak. Berdasarkan ini stroke yang timbul akibat hipertensi dapat dibedakan atas dua golongan yang gambaran patologi dan kliniknya berbeda. Pada pembuluh darah sedang, seperti a. karotis, a. vertebrobasilaris atau arteri di basal otak, perubahan patologiknya berupa aterosklerosis, dan manifestasi klinik nya adalah stroke iskemik. Di sini peranan hipertensi sebagai salah satu faktor risiko utama disamping faktor-faktor lain seperti diabetes mellitus, hiperlipidemia, merokok dan lainlain Pembuluh darah kecil otak, ialah cabang-cabang penetrans arteri yang menembus ke dalam jaringan otak, berukuran diameter 50-200 mikron (S. Sundari,2015)

Dasar kelainan pada pembuluh darah jenis ini adalah spasme dan lipohialinosis; spasme terjadi pada hipertensi akut seperti hipertensi maligna, dan manifestasi kliniknya adalah Infark lakunar. Lipohialinosis juga terjadi pada hipertensi kronik, pembuluh darah dengan lipohialinosis ini dapat mengalami mikroaneurisma yang dapat pecah dan terjadi Perdarahan Intraserebral. Berbeda dengan aterosklerosis, pada lipohialinosis hipertensi dapat dikatakan merupakan faktor penyebab satu-satunya (Thuillez,2005).

\section{Simpulan Dan Saran}

Stroke dikatakan sebagai gangguan fungsi syaraf akut yang disebabkan karena gangguan peredaran darah otak secara mendadak. Stroke terbagi dalam dua tipe, tipe pertama adalah stroke iskemik yang disebabkan kurangnya suplai darah ke otak dikarenakan menyempitnya atau tersumbatnya pembuluh darah Tipe yang kedua adalah stroke hemoragik yang disebabkan pecahnya aneurisma pada parenchyma otak atau pada rongga antara otak dan tengkorak sehingga menyebabkan terjadinya iskemik dan desakan pada jaringan otak. Banyak faktor yang dapat memengaruhi kejadian stroke, diantaranya yaitu umur,jenis kelamin, keturunan, ras, hipertensi, hiperkolesterolemia, diabetes melitus, merokok, aterosklerosis, penyakit jantung, obesitas, konsumsi alkohol, stres, kondisi sosial ekonomi yang mendukung,diet yang tidak baik,aktivitas fisik yang kurang dan penggunaan obat anti hamil. Namun dari banyaknya faktor yang memengaruhi kejadian stroke hanya hipertensi yang secara signifikan memengaruhi kejadian stroke.

\section{Daftar Rujukan}

American Academy of Neurology. (2017). Speak Up. National Institute of Neurological Disorders and Stroke. Accesed 6 September 2017.

American Heart Assocition, A. H. (2013). An update Definition of Stroke for the 21st Century. AHA Journal Vol. 44.

Yonata Ade,Arif Satri, (2016).Hipertensi Sebagai Faktor Pencetus Terjadinya Stroke. http://juke.kedokteran.unila.ac.id/index.php/majority/issue/view/55

Cintya AD,Yuliami S,dan Susila S. (2013). Gambaran Faktor Resiko dan Tipe Stroke pada Pasien Rawat Inap di Bagian Penyakit Dalam RSUD Kabupaten Solok Selatan Periode 1 Januari 2010-31 Juni 2012.jurnal Kesehatan Andalas.2013;2(2) 
Ghani, Lannywati, Laurentia K. Mihardja, Delima. (2016). Faktor Risiko Dominan Penderita Stroke di Indonesia. Buletin Penelitian Kesehatan, Vol. 44 No. 1, Maret 2016 : 49 58.

Ginsberg, Lionel. (2008). Lecture Notes Neurologi. Jakarta: Erlangga

Hariyono T. 2006. Hipertensi dan Stroke. SMF Ilmu Penyakit Syaraf RSUD Banyumas. http://www.tempointeraktif.com/medika/arsip/052002/pus1.htm.

Kementrian Kesehatan Republik Indonesia. (2013). Riset Kesehatan Dasar (RISKESDAS) 2013. Jakarta: Badan Penelitian dan Pengembangan Kesehatan Republik Indonesia

National Heart Lung and Blood Institute, (2008). High Blood Pressure UnitedStates.

Elizabeth J. Corwin. (2009). Buku Saku Patofisiologi Corwin.Jakarta: Aditya Media

Organisation WH. WHO. (2016)Stroke,Cerebrovascular accident. Stroke. doi:http://www.who.int/topics/cerebrovascular_accident/en/index.html.

Pokdi Stroke Perhimpunan Dokter Spesialis Saraf Indonesia (PERDOSSI).(2011). Guideline stroke tahun 2011. Jakarta: PERDOSSI

Sarini \& Suharyo. (2008). Beberapa faktor risiko yang berhubungan dengan kejadian stroke (studi kasus di RSUP dr. Kariadi Semarang). Jurnal Kesehatan Masyarakat Nasional 3(2):153-164

Sacco RL, Kasner SE, Broderick JP,et al.(2013) AHA/ASA Expert Consensus Document An Updated Definition of Stroke for the 21st century; 2064- 2089

Sundari, L., \& Merah, B. (2015). Faktor-faktor Yang Berhubungan Dengan Kejadian Hipertensi. Jurnal Keperawatan, XI (2), 216-223

Thuillez, V. Richard., (2005), Targeting Endothelial Dysfunction In Hypertensive subjects. Journal of human Hypertension. www.nature.com/jhh/journal/v 19/n1s/full/ 100189a.html. 